\title{
O tempo de sonhos não acabou
}

\section{The dreams time not over}

E xistem momentos na vida em que sentimos a necessidade de fazer um balanço das nossas atividades. Poucos se enquadram tão bem quanto esta ocasião em que recebo o honroso Prêmio Colégio Brasileiro de Cirurgiões.

Desde cedo carrego dentro de mim um núcleo de idéias e princípios fundamentais.. Com a experiência da vida alguns foram naturalmente deslocados para um segundo plano e outros aperfeiçoados. Eles nortearam a minha conduta e me levaram a acreditar e a sonhar. Sobre eles é que eu vou falar, incluindo alguns episódios que me marcaram. O meu tempo de sonhos não passou. Começa a diminuir o tempo para realizá-los !

Entendo a formação médica como um todo integrado e não uma simples soma de conteúdos das disciplinas e especialidades médicas. No ensino, na graduação e na residência, a prática é o grande motivador do aprendizado. Aprendizado baseado em problemas. O resultado final deve ser o cirurgião com profundos conhecimentos, competência técnica, formação humanitária ética e atuação socialmente responsável. Os médicos, em especial os cirurgiões, quando tomam suas decisões baseadas em evidência usam a ciência e quando as aplicam exercem a arte. Ciência e arte aplicadas com competência, dedicação, respeito e compaixão fazem do médico um Homem, uma Mulher Incomum. Eu disse Incomum e não Superior.

Acredito no médico e no cirurgião que tiveram em sua formação modelos exemplares, de médico e de professor, com os quais se possam identificar. Estabelecese assim a figura do mestre e do discípulo. Cada vez encontrados com menos freqüência em razão da setorização no ensino médico e da passagem rápida dos alunos e residentes pelos diversos estágios. E fazem falta.

Mestres como modelos exemplares e discípulos não se criam por decreto e não se compram. Crescem em conjunto, as vezes um questionando o outro ou com discordâncias, sem perda da harmonia e do respeito. Exige tempo e muita dedicação e do mestre consciência da importância de sua função. Quem é Mestre ? Quando se é discípulo?

Acredito no trabalho e no talento ( T T ). O trabalho exercido com alegria e prazer acaba repercutindo favoravelmente no ambiente. Para fazer bem é preciso gostar do que se faz. E para gostar é preciso saber o que se faz. Este semblante de satisfação e felicidade acaba modelando o nosso rosto e contagiando a todos os que nos cercam. O talento e a vocação para a medicina e cirurgia existem sim. Mas eles precisam ser estimulados no dia a dia de uma maneira continuada. Não com compensações financeiras. Embora relevante, o dinheiro deve ser conseqüência natural do trabalho. Sempre entendi que o médico deve ser bem remunerado. Quanto mais e melhor trabalhar, mais deve ganhar. Jamais, porém deve exercer a medicina e a cirurgia com a finalidade exclusiva do dinheiro !

Acredito na hierarquia e na meritocracia. Naquele Chefe que não vê o fenômeno só em suas aparências. Vai além. Pensa não só com profundidade mas também com largueza e generosidade. Domina o seu campo e faz freqüentes passeios pela vizinhança e sobretudo exerce a disciplina e hierarquia sem comprometer a dignidade dos subordinados. Tem habilidade em levá-los a fazer de boa vontade o que deve ser feito. Uma liderança conquistada pela conduta pessoal e pela meritocracia. É brilhante sem ser soberbo e sabe também quando transigir sem comprometer os princípios básicos e a sua autoridade. Sabe que a impunidade tolerada muitas vezes pressupõem cumplicidade. Orgulha-se dos seus feitos mas também das coisas que se negou a fazer. Sabe que ao abusar de privilégios esquecendo os princípios, acaba perdendo os dois.

Distingo com muita clareza a diferença entre credibilidade e celebridade, a diferença entre os que trabalham e produzem e os que estão em constante procura dos holofotes. Diferencio os que agem com superficialidade dos que agem com simplicidade. A superficialidade se concentra no óbvio e nas aparências. A simplicidade exige muita experiência e segurança. Transformar um ato cirúrgico complicado em simples e natural revela um profissional elegante e competente. Quem olha e assiste, pensa: como é fácil operar. Diferencio também a vivacidade da desonestidade. São vizinhas próximas e no nosso país muitas vezes consideradas sinônimas e se confundem.

Acredito no planejamento, na objetividade, na disciplina e na responsabilidade. E dentro desta insiro com destaque especial a pontualidade. Não a pontualidade escrava do relógio. Aquela organizada que facilita o trabaIho de todos aumentando até o tempo disponível para o lazer e a família. Questão de respeitar os outros e ser respeitado.

Acredito nos nossos alunos. Os melhores são selecionados para as Faculdades de Medicina. A evasão nos cursos superiores nos anos de 2001 a 2005 no Brasil foi de $22 \%$. Na medicina foi de 4\%. Na Universidade Federal do Rio Grande do Sul foi de 0,28\%. O campo da medicina e da cirurgia é tão abrangente que o aluno mais indeciso

Excerto do discurso proferido pelo ECBC Luiz Rohde quando Ihe foi concedido o Prêmio Colégio Brasileiro de Cirurgiões 2012. 
encontrará uma especialidade onde se realizar. (engenharia médica, medicina legal, medicina do esporte, administração da saúde, laboratórios, pesquisa, ensino e mais de trinta especialidades para prestar assistência..). Defendo uma seleção mais criteriosa para a seleção dos professores. Devem ter experiência compatível, gosto pelo ensino, produção consistente e atualizada e formação humanitária. Hoje as universidades abrem um edital para concurso. Em um museu em Viena encontrei um documento, no meio de tantos outros. Vejam como o imperador José ll sa Austria selecionava, em 1789, o cirurgião para a Universidade : "Faço saber que existe uma vaga para cirurgia em nossa Universidade. Não importa a sua origem e sua nacionalidade. Alem de ser reconhecido em seu saber deve ser respeitado pelos seus colegas. Deve gostar de ensinar, ter qualidade de liderança e saber quando transigir. E seria bom que tivesse todas estas qualidades, mas que ele mesmo não soubesse disto". José II, 1789.

Reforço o que disse aos meus afilhados quando paraninfo pela primeira vez, em 1973, "Por mais atarefados que estiverem não se afastem das associações de classe, ainda que discordem de sua orientação. Elas certamente farão mais com a participação de vocês". Reafirmo o que disse na ocasião. E os anos vieram provar a importância do nosso Colégio Brasileiro de Cirurgiões. A importância do Cirurgião Geral que ainda faz muita falta na assistência médica do país. A região do Rio Grande do Sul, ao norte de uma linha que une Porto Alegre a Uruguaiana é uma das mais bem servida de hospitais no mundo, diz a ONU. E faltam cirurgiões gerais. Creio que não é diferente em outras regiões do país. Ñão os cirurgiões gerais de alta complexidade também tão úteis. Estes precisam hospitais de primeira linha e se enquadram numa outra ordem. Os cirurgiões de procedimentos não tão complexos, de pequeno e médio porte, estes cirurgiões faltam e são úteis e necessários. Tem uma das maiores taxas na resolução de problemas da saude. Em seu trabalho enquadram-se perfeitamente na frase do Presidente Norte-americano
Theodore Roosevelt: "Do what you can, where you are, with what you have".

Considero equivocada a filosofia de formar mais médicos com a finalidade de forçá-los a trabalhar nos lugares privados de assistência. A relação no país é de 1,9 Médicos: para 1000 habitantes. É desejo do MEC em 2014 atingir 2,5: 1000 habitantes. É uma política que tem se mostrada enganosa. Em junho deste ano foi publicado no Diário Oficial a criação para o ano de 2014 o Instituto Nacional de Supervisão e Avaliação da Educação Superior com 550 cargos. Fazendo parte, entendo que na área médica é o momento de criar o Conselho Superior de Avaliação, do médico que produzimos, do médico que necessitamos e avaliação das Faculdades que os formam. Embora a louvável iniciativa do Conselho Regional de São Paulo em avaliar médicos formados, foram 4821 em 7 anos, com reprovação de 46,7\%. Neste ano de 2012 em 28 escolas a reprovação foi de $54,5 \%$. Entendo que esta aplicação deveria ser feita em duas provas: no início do internato e no fim, em todas as Faculdades do país. De acordo com as deficiências detectadas, tomar as medidas necessárias. Uma avaliação deve carregar consigo esperanças e trazer ameaças. Ambas são essenciais para o seu êxito. Se ninguém se sentir ameaçado, a avaliação certamente não será suficientemente penetrante. Se não acenar para uma perspectiva de mudança para melhor, é um gasto inútil.

E muito obrigado ao CBC: Capítulo do Rio Grande do Sul, ao Diretório Nacional e ao Conselho Superior, por esta honrosa distinção.

No meu discurso passeei pela Holanda, Áustria, Estados Unidos, Italia. Para finalizar volto ao meu Rio Grande do Sul. Ao visitar uma pequena cidade do interior, no pórtico de entrada encontrei o seu emblema: Arbeit, Freude und Blumen. De uma maneira concisa é o que desejo para o cirurgião quando se forma: Arbeit, Freude und Blumen Trabalho, Alegria e Flores. É o que desejo também para todos vocês !!! 